\title{
IMAGES IN MEDICAL PRACTICE
}

\author{
MMR SIDDIQUI $^{\mathrm{a}}$, QT ISLAM ${ }^{\mathrm{b}}$, A HOSSAINc, MS MAHBUB ${ }^{\mathrm{d}}$
}

(J Bangladesh Coll Phys Surg 2010; 28: 202)

A 40-year-old previously healthy house wife presented with fever for 1 months and swelling of the lower lip for 15 days. Initially her lower lip became swollen and after 7 days it became ulcerated without any pain (fig1). Clinical examination revealed she was febrile with swollen, ulcerated, crusted lower lip. Her upper lip and mouth cavity were absolutely normal. Other clinical examinations were unremarkable.

A 14-year-old previously healthy school boy presented with fever for 6 weeks and gradual protrusion of the both eyes for 20 days. Clinical examination revealed he had fever, bony tenderness, purpura and bilateral proptosis (fig-2). He had no eye pain, chemosis or congestion. Thyroid gland was normal.
In both cases investigations revealed they had acute myeloid leukemia (AML) with possible deposition of leukemic cells (blast) in lip and retro-bulbar tissue respectively. In AML, malignant clones of immature myeloid cells (primarily blasts) proliferate, replace bone marrow, circulate in blood and invade other tissues. ${ }^{1,2}$ Leukemic cells may infiltrate any extra-medullary site occurring in approximately $3 \%$ of patients with AML. ${ }^{1,2}$

\section{References:}

1. Rajput D, Naval R, Yadav K, Tungaria A, Behari S. Bilateral proptosis and bitemporal swelling: A rare manifestation of acute myeloid leukemia. J Pediatr Neurosci 2010;5:68-71.

2. Paydas S, Zorludemir S, Ergin M. Granulocytic sarcoma: 32 cases and review of the literature. Leuk Lymphoma. 2006;47:2527-2541.

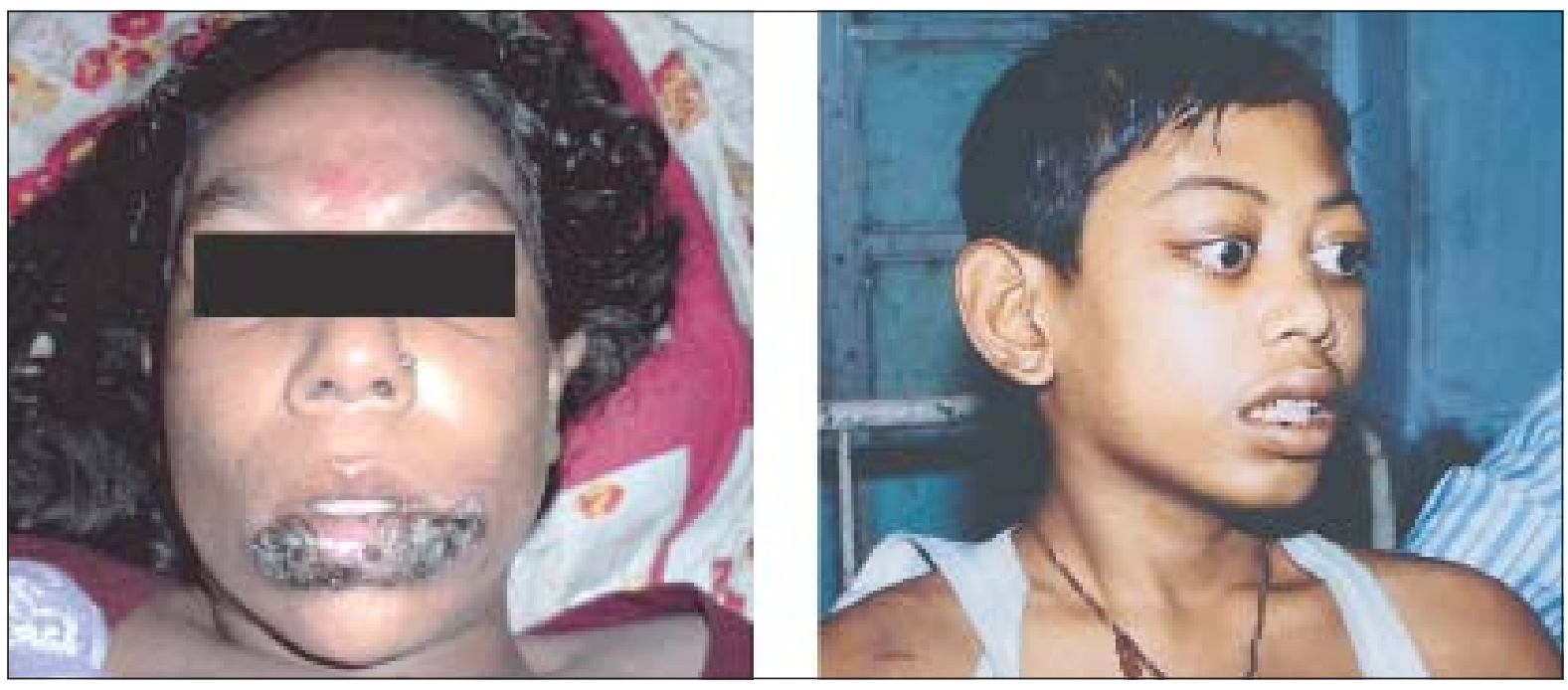

a. $\quad$ Dr. Md. Mahmudur Rahman Siddiqui, FCPS (Med) Part-II Course student, Dept. of Medicine, DMCH, Dhaka.

b. Prof. Quazi Tarikul Islam, Professor, Dept of Medicine, DMCH, Dhaka.

c. Dr. Ahmed Hossain, Assistant Professor, Dept. of Medicine, DMCH, Dhaka.

d. Dr. Md. Shahriar Mahbub, FCPS (Med) Part-II Course student, Dept. of Medicine, DMCH, Dhaka. 